\title{
INTEGRAL ASSESSMENT OF STRESS-DEFOMATED CONDITION OF METAL STRUCTURES OF MACHINES UNDER THE ACTION OF STATIC AND DYNAMIC LOADS
}

\section{ІНТЕГРАЛЬНА ОЦІКА НАПРУЖЕНО-ДЕФОМОВАНОГО СТАНУ МЕТАЛОКОНСТРУКЦІЙ МАШИН ПІД ДІЕЮ СТАТИЧНИХ ТА ДИНАМІЧНИХ НАВАНТАЖЕНЬ}

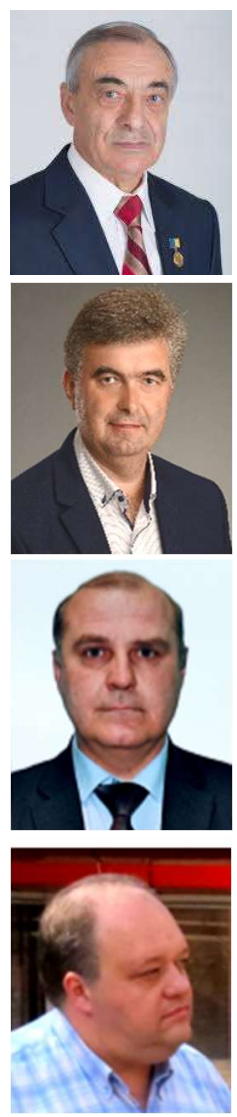

\begin{abstract}
Nazarenko Ivan Ivanovich, Doctor of Technical Sciences, Professor, Kiev National University of Construction and Architecture, Head of the Department of Machines and Equipment for Technological Processes, i_nazar@i.ua, tel.: +38096-148-81-52, https: // orcid. org / 0000-0002-1888-3687
\end{abstract}

Kuzminets Mykola Petrovych, Doctor of Technical Sciences, Professor, National Transport University, Head of the Department of Computer, Engineering Graphics and Design, kuzminecmp@ukr.net, tel.+380442849713,

https://orcid.org/0000-0002-9636-919X

Dedov Oleg Pavlovich, Doctor of Technical Sciences, Associate Professor, Kiev National University of Construction and Architecture, Department of Machines and Equipment for Technological Processes, dedovvcbk@ukr.net, tel.: 067-588-90-84, https://orcid.org/0000-0001-5006-772X

Zalisko Igor Igorovych, Candidate of Technical Sciences, Director of the company "Production and Commercial Firm Drohobych Truck Crane Plant", lion677889@gmail.com.

Abstract. The article considers a system that combines the influence of static on dynamic loads on the example of the support-rotary circuit of a truck construction crane. The position of the system and its elements with the highest loads is revealed, the method of creating steel structures is investigated, each element, depending on the average load, experiences a stress-strain state. The basic laws of the theory of elasticity and plasticity were used to build a calculated mathematical model of the loaded support-rotary circuit. Equations of motion were compiled taking into account the behavior of structural elements and the machine as a whole under the simultaneous action of different loads.

The calculation scheme was taken in the form of a structure consisting of rods rigidly connected to each other in nodes. As a method of calculation the method of finite elements with definition of displacements (deformations), efforts (stresses) in nodes of a grid of constructive elements of a design of a basic-rotary contour is applied. The stress distribution in each structural element depending on the type of load was obtained. This distribution allowed to choose rational parameters of a design in each its section. The proposed approach allowed to create a solid structure that provides reliability and economy of material. Thus, the results obtained allowed to fully analyze and decide on the simultaneous provision of strength, rigidity and minimum material consumption of the structure. 
Keywords: modeling, machine, stress-strain state of metal structures, diagnostic systems, support-rotary circuit, dynamic loading.

Purpose and methods. The modern development of construction in Ukraine puts forward new requirements for equipment that would ensure high reliability, performance, and a range of economic and ergonomic requirements. To a large extent this applies to steel structures construction vehicles and equipment, demand for which is growing every year. The solution of this problem lies in the direction of improving the design, the identification of the potential of existing structures, improving their productivity and efficiency, the development of diagnostic systems.

Metal construction machines of various technological purpose in the operation accept both static and dynamic loads and tend to work in the mode of alternating load, the effectiveness of such cars due to software defined technology modes and parameters impact on the processed material, which can be realized by careful selection of mathematical calculation models that adequately reflect the actual motion of the system.

Modern machinery provides a solution to a number of issues that are caused by factors of a different nature. The main factor influencing the implementation of projects of construction of new machines are purpose requirements of today's market and directly to consumers of such technology.

Over time, the appearance of new construction materials and technologies for their manufacture and processing, the vector of development of engineering change its direction. Undoubtedly, the design requirements of modern machines and high stiff enough, but the fundamental concepts of what the machine has to be changed somewhat.

That is, when it comes to modern technological machine, is to identify the main issues to be addressed $[1,2]$ : a low power consumption of the implementation process with a high quality; low consumption of materials; high reliability; certain durability; low manufacturing cost.

In carrying out theoretical studies [1-3], as well as practical implementation [1-6], it began the scientific study of the problem: the development of the most effective and reliable construction machines for different loads, provided by the establishment and management of changes in domestic laws (elastic and dissipative) properties of the system "vehicle - environment".

The goal of the work. In recent years, development and creation of construction machines of various technological purpose being to find ways of constructive solutions with a variable. In operation of such machines is assumed maximum utilization of internal resources to the machine in turn makes it necessary to ensure durability and reliability with desired dynamic parameters. Production of such a problem is to determine the intensity of the structural elements of the machine and the assessment of their stress-strain state.

Results and explanations. An integrated assessment of the condition of the metal structures of the machine can be performed on the basis of dynamic tests. The idea of such tests is to find the actual dynamic characteristics of the structure (natural frequency, oscillation amplitude, etc.) with subsequent comparison of these characteristics with the characteristics obtained by mathematical modeling of the system. The mathematical model should be designed to adequately describe the actual design and its behavior under different loads, and be able to reflect the simulation of various imperfections associated with the manufacture and direct operation for its intended purpose.

Under dynamic loads on structural elements, which are inherent in most machines for technological purposes, the main type of damage is the formation and development of cracks due to the accumulation of fatigue stresses. Durability in fatigue failure is determined by the long-term cyclic action of loads on the loadbearing structures of the machine and its individual elements, resulting in a crack, gradually develops and leads to failure.

The solution of the problem of determining the study of the stress-strain state is carried out by using a comprehensive approach that combines analytical calculations, mathematical modeling and direct experimental research.

To implement these tasks, the following sequence of studies was provided: 
analysis of the behavior of the structural elements of the machine in terms of taking into account all types of loads that were carried out during its operation and determining the possible set of loads acting on the elements;

development of the calculation model of the object of research taking into account the general or separate most loaded knots or constructive elements;

compilation of equations of motion taking into account the behavior of structural elements and the machine as a whole with the simultaneous action of various loads;

ssessment of real loads for the development of an algorithm for determining the stress-strain state, identifying the most stressed structural elements;

development on a computer model of a matrix of control points of limit values of integral characteristics of a condition of a design for the further application at full-scale tests;

computer calculations to determine stresses and strains by applying a number of possible loads on the model;

development and carrying out of experimental researches on the samples reflecting real conditions of work of a detail or unit of the machines;

adjustment of the computer model as long as the comparison of the integral characteristics obtained by measurements at the control points during the experiment and during the simulation may differ within the allowable error (thus obtained computer model will be adequate to the actual design within the points adequacy - control points of integral characteristics);

development of recommendations for improvement of the existing or creation of a new design which corresponded to the basic idea of uniformity of distribution of pressure irrespective of the applied forces on elements of the loaded product.

Analysis of possible loads was carried out on the basis of research on the example of truck cranes [4]. This is due to the fact that these machines are a classic example of the structure of the system, which organically combines static and dynamic loads, which require proper consideration for safe operation of the crane in terms of its actual load. The basic laws of the theory of elasticity and plasticity were used to build a calculated mathematical model of the loaded defense industry [4].

Equations of motion were compiled taking into account the behavior of structural elements and the machine as a whole under the simultaneous action of different loads. In the case of a dynamic action on its metal structure (Fig. 1), as a linear elastic body, the equations of motion in the adopted coordinate system (Fig. 2) have the form:

In the case of dynamic performance on metal structure as a linear elastic body, equation of motion has the form:

$$
z_{i j, j}+F_{i}=\rho \cdot U_{i}
$$

Where $z_{i j, j}$ - stress tensors, $(i, j=1,2,3)$;

$F_{i}$ - components of bulk forces;

$\rho$ - density material;

$U_{i}$ - vector of movements.

Given the viscous properties then replace in (1) the operator:

$$
\rho \cdot \frac{\partial^{2}}{\partial \mathrm{t}^{2}} \Leftrightarrow \rho\left(\frac{\partial^{2}}{\partial \mathrm{t}^{2}}\right)+\mathrm{k} \frac{\partial}{\partial \mathrm{t}}
$$

where $k$ - viscosity.

Equation (2) as such remains unchanged. 


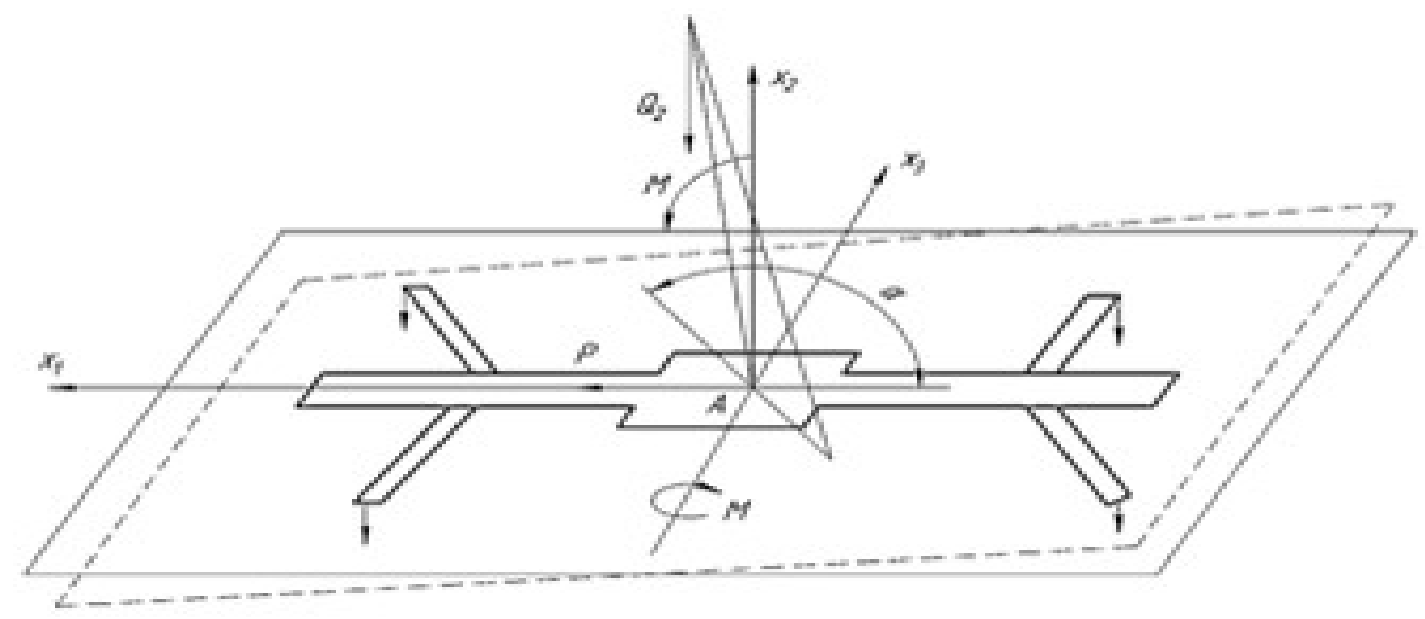

Figure 1 - Calculation scheme of the reference circuit of the truck crane

Рисунок 1 - Розрахункова схема опорного контуру автокрана

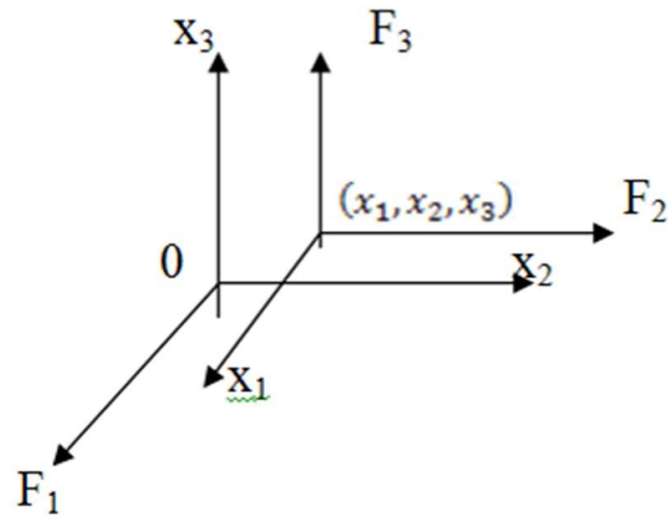

Figure 2 - The coordinate system of the acting forces on the reference circuit of the car

Рисунок 2 - Система координат діючих сил на опорний контур автомобіля

The notation of the wave propagation velocity in the crane support rotary device is introduced

$$
C_{1}^{2}=\frac{1-v}{(1+v)(1-2 v)} \cdot \frac{E}{\rho} ; C_{2}^{2}=\frac{1}{2(1+v)} \cdot \frac{E}{\rho}
$$

For the case when the force $\mathrm{F}(\mathrm{t}$ ) is common and operates along the axis OX1 (at the beginning of the coordinate system)

$$
\mathrm{U}_{1}\left(\mathrm{x}_{1}, \mathrm{x}_{2}, \mathrm{x}_{3}, \mathrm{t}\right)=\frac{1}{4 \pi \rho \mathrm{R}} \cdot\left[\frac{1}{\mathrm{C}_{1}^{2}} \cdot \frac{\mathrm{x}_{1}^{2}}{\mathrm{R}^{2}} \cdot \mathrm{P}\left(\mathrm{t}-\frac{1}{\mathrm{C}_{1}}\right)+\frac{1}{\mathrm{C}_{1}^{2}} \cdot\left(1-\frac{\mathrm{x}_{1}^{2}}{\mathrm{R}^{2}}\right) \mathrm{P}\left(\mathrm{t}-\frac{1}{\mathrm{C}_{1}}\right)-\left(1-3 \frac{\mathrm{x}_{1}^{2}}{\mathrm{R}^{2}}\right) \cdot \int_{\frac{1}{\mathrm{C}_{1}}}^{\frac{1}{\mathrm{C}_{2}}} \lambda \mathrm{P}(\mathrm{t}-\right.
$$

$\lambda \mathrm{R}) \mathrm{d} \lambda]$

$$
\begin{aligned}
& \mathrm{U}_{2}\left(\mathrm{x}_{1}, \mathrm{x}_{2}, \mathrm{x}_{3}, \mathrm{t}\right)=\frac{\mathrm{x}_{1} \mathrm{x}_{2}}{4 \pi \rho} \cdot\left[\frac{1}{\mathrm{C}_{1}^{2}} \cdot \mathrm{P}\left(\mathrm{t}-\frac{\mathrm{R}}{\mathrm{C}_{1}}\right)-\frac{1}{\mathrm{C}_{1}^{2}} \cdot \mathrm{P}\left(\mathrm{t}-\frac{\mathrm{R}}{\mathrm{C}_{2}}\right)+3 \int_{\frac{1}{\mathrm{C}_{1}}}^{\frac{1}{\mathrm{C}_{2}}} \lambda \mathrm{P}(\mathrm{t}-\lambda \mathrm{R}) \mathrm{d} \lambda\right] \\
& \mathrm{U}_{3}\left(\mathrm{x}_{1}, \mathrm{x}_{2}, \mathrm{x}_{3}, \mathrm{t}\right)=\frac{\mathrm{x}_{1} \mathrm{x}_{3}}{4 \pi \rho \mathrm{R}} \cdot\left[\frac{1}{\mathrm{C}_{1}^{2}} \cdot P\left(\mathrm{t}-\frac{\mathrm{R}}{\mathrm{C}_{1}}\right)-\frac{1}{\mathrm{C}_{1}^{2}} \cdot \mathrm{P}\left(\mathrm{t}-\frac{\mathrm{R}}{\mathrm{C}_{2}}\right)+3 \int_{\frac{1}{\mathrm{C}_{1}}}^{\frac{1}{\mathrm{C}_{2}}} \lambda \mathrm{P}(\mathrm{t}-\lambda \mathrm{R}) \mathrm{d} \lambda\right] .
\end{aligned}
$$


If the force acts along the axis OX2, then you have to replace the index:

$$
y(22) \Rightarrow\left\{\begin{array}{l}
1 \rightarrow 2 \\
2 \rightarrow 3 \\
3 \rightarrow 1
\end{array}\right.
$$

If the force acts along the axis OX 3 , then you have to replace the index:

$$
y(22) \Rightarrow\left\{\begin{array}{l}
1 \rightarrow 3 \\
2 \rightarrow 1 \\
3 \rightarrow 2
\end{array}\right.
$$

For the plane problem $(\mathrm{x} 3=0)$; for one-dimensional problems: $(\mathrm{x} 1 \neq 0 ; \mathrm{x} 2=\mathrm{x} 3=0)$.

So, as a result of dependencies are as follows: using Cauchy relations, Hooke's law and relations that bind Lame elastic constants of Young's modulus, shear modulus and Poisson's ratio is decisive for calculating the stress-strain state of stresses in reference circle of application solutions in the form of third-rank tensor (Fig. 3):

$$
\begin{gathered}
\mathrm{V}_{\mathrm{ijk}}\left(\mathrm{x}_{1}, \mathrm{x}_{2}, \mathrm{x}_{3}\right)=\frac{1}{8 \pi(1-v)} \frac{1}{\mathrm{R}^{3}}\left[(1-2 v) \cdot\left(\mathrm{x}_{\mathrm{k}} \cdot \delta_{\mathrm{ij}}-\mathrm{x}_{\mathrm{i}} \cdot \delta_{\mathrm{jk}}-\mathrm{x}_{\mathrm{j}} \cdot \delta_{\mathrm{ki}}\right)-3 \frac{\mathrm{x}_{\mathrm{i}} \mathrm{x}_{\mathrm{j}} \mathrm{x}_{\mathrm{k}}}{\mathrm{R}^{2}}\right], \\
\mathrm{V}_{\mathrm{ijk}}\left(\mathrm{x}_{1}, \mathrm{x}_{2}, \mathrm{x}_{3}\right)=\frac{1}{8 \pi(1-v)} \frac{1}{\mathrm{R}^{3}}\left[(1-2 v)\left(\mathrm{x}_{\mathrm{k}} \cdot \delta_{\mathrm{ij}}-\mathrm{x}_{\mathrm{i}} \cdot \delta_{\mathrm{jk}}-\mathrm{x}_{\mathrm{j}} \cdot \delta_{\mathrm{ki}}\right)-3 \frac{\mathrm{x}_{\mathrm{i}} \mathrm{x}_{\mathrm{j}} \mathrm{x}_{\mathrm{k}}}{\mathrm{R}^{2}}\right], \\
\quad(\mathrm{i}=1,2,3) .
\end{gathered}
$$

In this case, the right kind of movement will be: $\mathrm{U}_{\mathrm{i}}\left(\mathrm{x}_{1}, \mathrm{x}_{2}, \mathrm{x}_{3}\right)=\mathrm{U}_{\mathrm{ij}}\left(\mathrm{x}_{1}, \mathrm{x}_{2}, \mathrm{x}_{3}\right) * \mathrm{~F}_{\mathrm{j}}\left(\mathrm{x}_{1}, \mathrm{x}_{2}, \mathrm{x}_{3}\right)$, $(i=1,2,3)$.

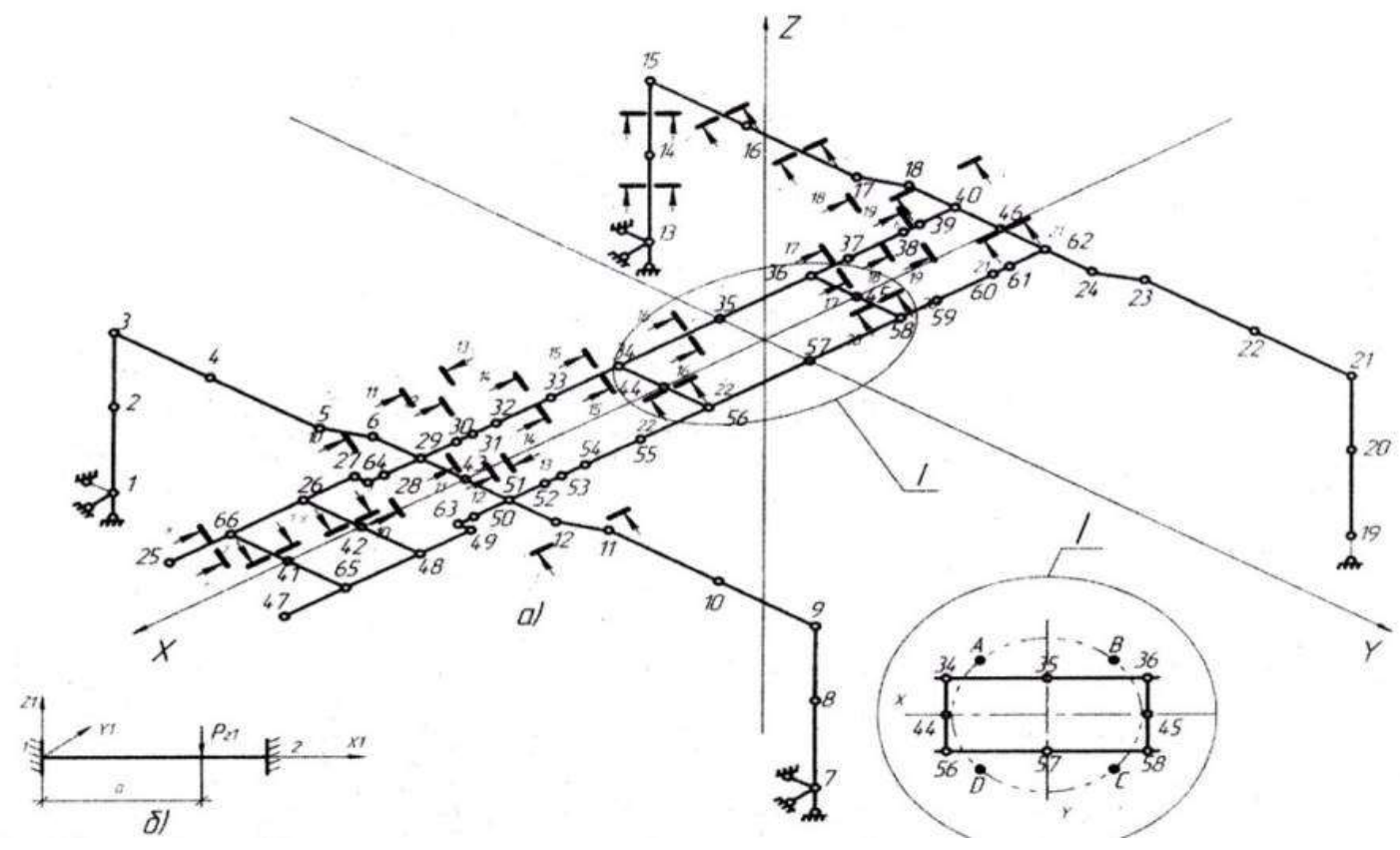

Figure 3 - Estimated scheme of the crane frame

Рисунок 3 - Розрахункова схема рами автокрана 
Design model frame with outriggers shown in Fig. 3 as well. Design model adopted in the form of construction consisting of rods rigidly interconnected the nodes. Units conventionally shown as small circles numbered in Arabic numerals. Serial number of the rod (item) affixed in a circle. Each rod section is now with geometrical characteristics. Design model building on a line connecting the centers of gravity of cross sections of rods.

Design model is in rectangular coordinates $\mathrm{X}, \mathrm{Y}, \mathrm{Z}$ (general coordinate system). The result of the calculation of finite element of this design is shown in Fig. 4.

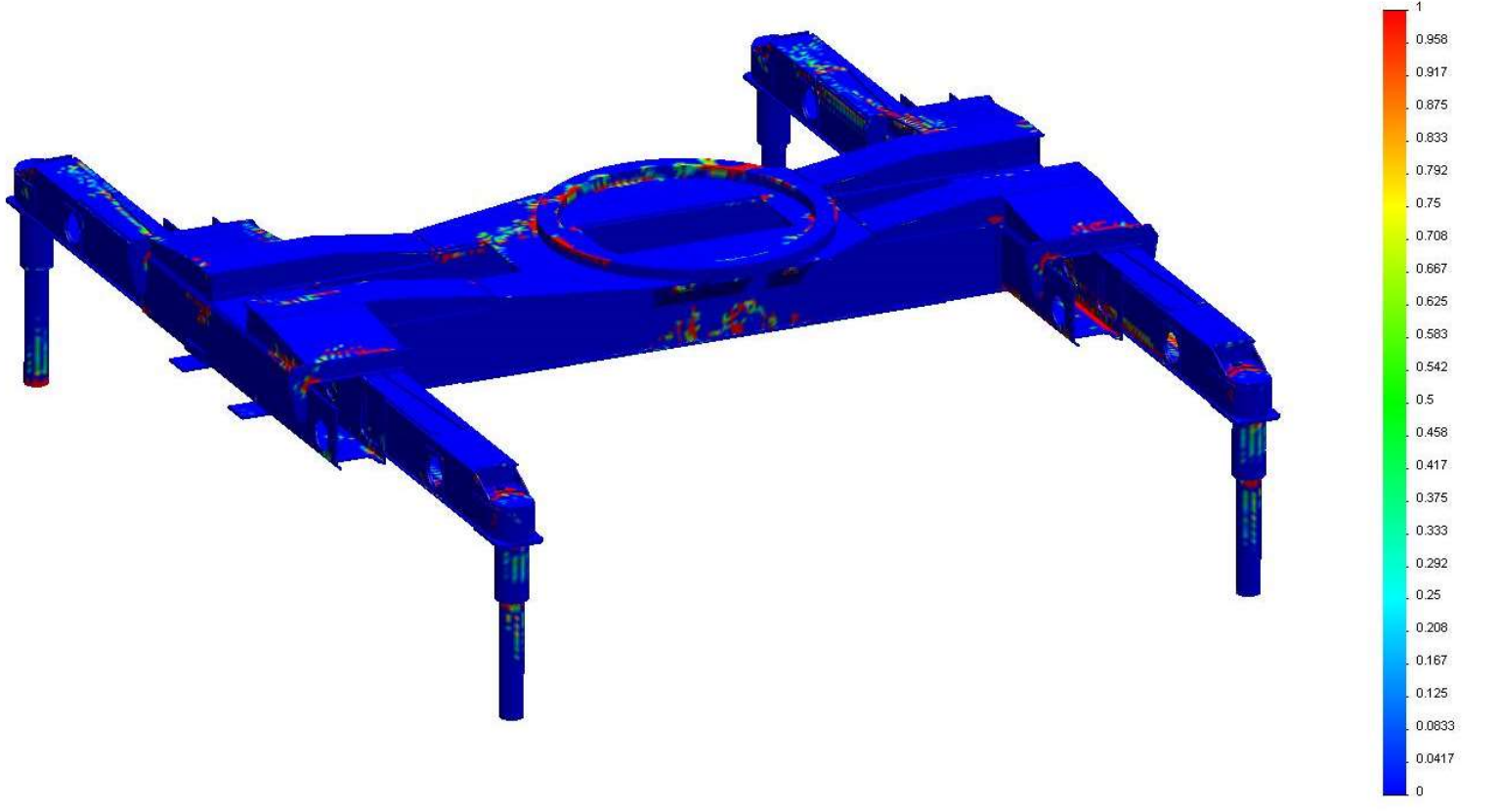

Figure 4 - The result of the calculation of the crane frame

Рисунок 4 - Результат розрахунку рами автокрана

The correctness of the results of mathematical modeling to a greater extent depends on the mechanical properties of structural materials and the study of complex work units bearing structural elements. Test procedures for mechanical characteristics of the static effect is to create a load on the test sample in order to create in it a certain kind of stress (tension, compression, shear). Thus a tensile test determined the basic mechanical characteristics not only of constructional materials, and their connection to each other (Fig. 5a). Quite often undergo static tests not only the individual samples of the materials, but entire units (Fig. 5b) future construction in order to study their stress-strain state and evaluation of stiffness.

It was found that the maximum loads occur in the position of the crane installation, perpendicular to the main axis of the vehicle on which the crane installation is fixed. It was found that of all the nodes of the crane installation, the greatest stresses occur in the Support rotary crane, which provides rotation of the lifting mechanism by 360 degrees. By changing the dynamic and static loads and analyzing the results obtained in Figure 6 , the results of the research were changed in the design of the defense industry so that all elements had one order of numerical values of stresses, which in the final design allowed to reduce the mass of the defense industry by $30 \%$. 


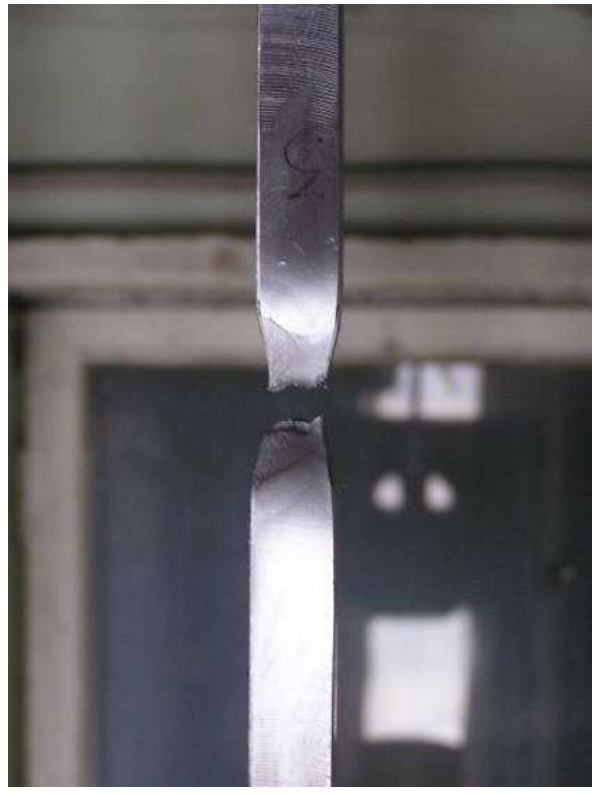

a)

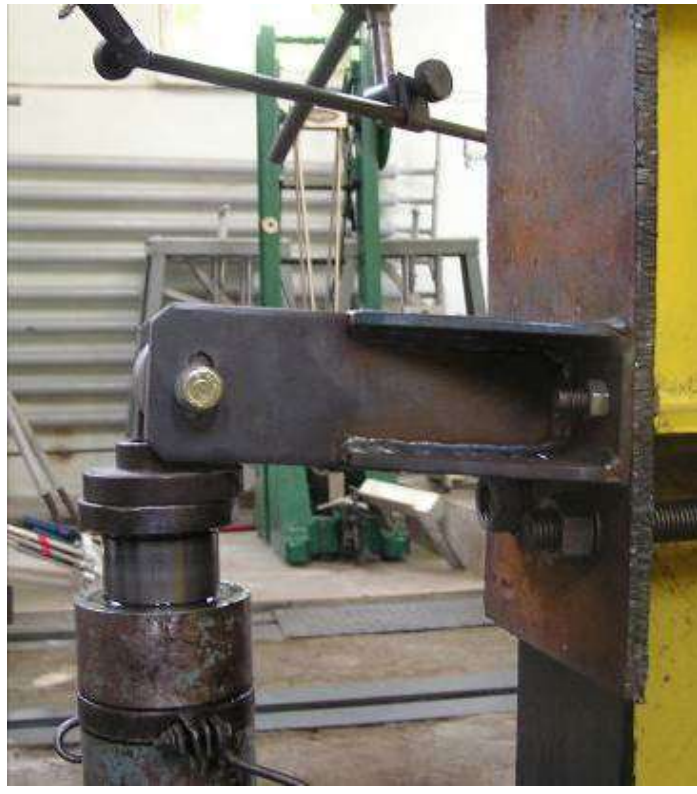

b)

Figure 5 - Testing of structural elements of metal structures:

a) - tensile welded joint; $b$ ) - bracket strength test

Рисунок 5 - Випробування конструктивних елементів металоконструкцій: а) - випробування зварного з'єднання на розтяг; б) - випробування кронштейна

Integral assessment of the metal structures of the finished product can be made on the basis of the dynamic tests. The idea of testing is to find the actual dynamic characteristics of the structure (natural vibration frequency, vibration amplitude, etc.) and then comparing these characteristics with the characteristics obtained by mathematical simulation of the system design. The mathematical model must be created so that adequately describes the real structure and its behavior under various loads and the ability to reflect the simulations of various kinds of defects associated with the manufacture and operation of the immediate appointment.

At the dynamic loads on structural elements inherent in most vehicles technological purpose, the main type of damage is the formation and development of cracks caused by the accumulation of stress fatigue. Durability destruction determined long cycles of stresses on the supporting structure of the machine and its individual elements, resulting in a crack gradually develops and leads to destruction.

Calculation and testing of individual elements of the design of the machine is not too difficult, although in some cases require a lot of material resources and time-consuming. When it comes to more complex parts and assembly units of the accuracy of the analytical calculation is subject to doubts in terms of the rational use of materials, resulting in an increase in material consumption structure, and further the energy intensity of the whole technological process, which performs such a design.

It is obvious that the solution of this problem lies in the integrated approach should combine analytical calculations, mathematical modeling and direct experimental studies.

To implement this approach assumes the following sequence of research work:

- analysis calculation of structural elements of the machine in terms of for all types of loads that were made in the design of the machine;

- the development of a computer model of the object of study (general or individual most loaded components, structural elements);

- determining a possible combination of loads acting on the elements; 
- conduct additional simulations and calculations to determine the behavior of structural elements and the whole machine while the action of various loads (if necessary);

- verification of design decisions and the choice of the most efficient, by modeling teamwork loads on computer models, evaluation and analysis of stress-strain state, identify the most stressful elements of the structure;

- to develop a computer model of the matrix control points limits the integral characteristics of the state of design for future use in field trials;

- conducting full-scale and model (computer experiments) by applying certain loads on the real sample and its model;

- adjusting the computer model until the comparison is integral characteristics obtained by measurements at control points during the experiment and the simulation will differ among themselves within the allowable error (the thus obtained computational model is adequate actual design within the points adequate integral control points characteristics).

To construct a mathematical model can be used general purpose computational systems, which are based on numerous calculations and the fundamental laws of the theory of elasticity, plasticity, and the like. Recently, such settlement systems have been widely used in various industries, including mechanical engineering. The results of analysis of structures by numerical methods (eg finite element method) is a movement (deformation), effort (stress) at the nodes of the mesh design of the structure. Depending on the need for rational calculation accuracy, the number of nodes and finite elements, respectively, can be measured in hundreds and thousands. On the one hand the processing of the results of such calculations is time-consuming, but allows at the design stage to obtain a general picture of the structural layout of the machine components and the improvement of its conduct in terms of the rational use of materials. In the case of upgrading an existing machine model of technological purpose, calculation model in this sector, will allow to analyze the technical level of the design and fulfill its forecasting reliability, and in conjunction with the implementation of the pilot studies to assess the current technical condition of the appearance of possible failures, and the like.

\section{Conclusions and recommendations:}

1. The analysis methods of modeling and machine indicates the need to consider the stress-strain state of the steel structures.

2. Proposed methodology and test methods for machines under static and dynamic loading, the way the software determine the load on the metal machine.

\section{References}

1. Nazarenko I.I. Applications of the theory of vibrating systems (second edition). K.: Publishing House "Word." $2010-440 \mathrm{p}$.

2. Nazarenko I.I. Fundamentals of design and construction of machinery and equipment of processing manufactures / I.I. Nazarenko, I.M. Bernik // - K.: LLC "Agrar Media Group», 2013. - 544 p.

3. Nazarenko I.I. Vibrating machines and processes of the construction industry: - K.: KNUCA, 2007. - 203 p.

4. Zalisko I.I. Study of influence of technology factors on durability of the support frame / I.I. Zalisko // Mountain, building, road, reclamation machines - K .: KNUCA, 2012. - №80. - P. 44 - 88.

5. Dedov O.P. / Mathematical model and determination of parameters of movement compactors for soil compaction. / O.P.Dedov // Mountain, building, road, reclamation machines .№ 66, Kiev, 2006, P.41-46.

6. Kuzminets M.P. Evaluation of the reliability of the results of numerical modeling of the stress state of metal structures of switch machines for soil compaction under the pipeline.: PDBA. Issue No. 46. Hoisting-andtransport, construction and road machines and equipment. 2008.- S. 84-91. 


\section{ІНТЕГРАЛЬНА ОЦІНКА НАПРУЖЕНО-ДЕФОМОВАНОГО СТАНУ МЕТАЛОКОН- СТРУКЦІЙ МАШИН ПІД ДІЕЮ СТАТИЧНИХ ТА ДИНАМІЧНИХ НАВАНТАЖЕНЬ}

Назаренко Іван Іванович, доктор технічних наук, професор, Київський національний університет будівництва та архітектури, завідувач кафедри машин та обладнання для технологічних процесів, i_nazar@i.ua, тел .: + 38096-148-81-52, https : // orcid. орг / 0000-0002-1888-3687

Кузьмінець Микола Петрович, доктор технічних наук, професор, Національний транспортний університет, завідувач кафедри комп'ютерної, інженерної графіки та дизайну, kuzminecmp@ukr.net, тел. +380442849713, https://orcid.org/0000-0002-9636-919X

Дедов Олег Павлович, доктор технічних наук, доцент, Київський національний університет будівництва та архітектури, кафедра машин та обладнання для технологічних процесів, dedovvcbk@ukr.net, тел .: 067-588-90-84, https: // orcid.org/0000-0001-5006-772X

Заліско Ігор Ігорович, кандидат технічних наук, директор компанії "Виробничо-комерційна фірма Дрогобицький завод автокранів", lion677889@gmail.com.

Анотація. В статті розглянуто систему, що поєднує вплив статичних на динамічних навантажень на прикладі опорно-поворотного контуру автомобільного будівельного крану. Виявлено положення системи та її елементів з найбільшими навантаженнями, досліджений метод створення сталевих конструкцій, кожен елемент в залежності від середньої завантаження відчуває напружено-деформованого стану. Для побудови розрахункової математичної моделі навантаженого опорно-поворотного контуру були використанні основні закони теорії пружності та пластичності. Були складені рівняння руху із урахуванням поведінки конструктивних елементів та машини в цілому при одночасній дії різноманітних навантажень. Розрахункова схема приймалася у вигляді конструкції, що складається із стержнів жорстко з'єднаних між собою у вузлах Для кожного стержня даний переріз приведений з геометричними характеристиками. У якості методу розрахунку застосовано метод скінченних елементів з визначенням переміщень (деформації), зусиль (напружень) у вузлах сітки конструктивних елементів конструкції опорно-поворотного контуру. Було отримано розподіл напружень в кожному елементі конструкції в залежності від виду навантаження. Цей розподіл дозволив вибрати раціональні параметри конструкції в кожному її перетині. Запропонований підхід дозволив створити рівноміцну конструкцію, що забезпечує надійність та економію матеріалу. Таким чином отримані результати дозволили в повній мірі проаналізувати та прийняти рішення щодо одночасного забезпечення міцності, жорсткості і мінімальної матеріаломісткості конструкції.

Ключові слова: моделювання, машина, напружено-деформований стан металевих конструкцій, діагностичні системи, опорно-поворотний контур, динамічне навантаження.

\section{Перелік посилань}

1. Назаренко І.І. Застосування теорії вібраційних систем (друге видання). К .: Видавництво «Слово». 2010 $-440 \mathrm{c}$.

2. Назаренко I.I. Основи проектування та конструкції машин та обладнання переробних виробництв / I.I. Назаренко, І.М.Берник // - К .: ТОВ "Аграр Медіа Груп", 2013. - 544 с.

3. Назаренко І.І. Вібраційні машини та процеси будівельної галузі: - К .: КНУКА, 2007. - 203 с.

4. Заліско I.I. Вивчення впливу технологічних факторів на довговічність опорної рами / I.I. Заліско // Гірські, будівельні, дорожні, меліоративні машини - К.: КНУБА, 2012. - №80. - С. 44 - 88.

5. Дедов О.П. / Математична модель та визначення параметрів ущільнювачів руху для ущільнення грунту. / О.П.Дедов // Гірські, будівельні, дорожні, меліоративні машини. № 66, Київ, 2006, С.41-46.

6. Кузьмінець М.П. Оцінка надійності результатів чисельного моделювання напруженого стану металевих конструкцій комутаційних машин для ущільнення грунту під трубопроводом .: ПДАБА. Випуск № 46. Підйомно-транспортні, будівельні та дорожні машини та обладнання. 2008.- С. 84-91. 